\title{
Short-Term Effects of Maize Rhizosphere and N-Fertilization on Stable Organic Matter in a Tropical Soil
}

\author{
Rafael da Silva Teixeira ${ }^{1}$, Rafael Silva Santos ${ }^{1}$, Rodrigo Nogueira de Sousa ${ }^{1}$, Ivan Francisco de Souza ${ }^{1}$, \\ Thalles Guimarães Reis ${ }^{1}$, João José de Miranda Milagres ${ }^{1} \&$ Ivo Ribeiro da Silva ${ }^{1}$ \\ ${ }^{1}$ Departamento de Solos, Universidade Federal de Viçosa, Viçosa, Minas Gerais, Brazil \\ Correspondence: Rodrigo Nogueira de Sousa, Departamento de Solos, Universidade Federal de Viçosa, Viçosa, \\ Minas Gerais, CEP: 36570-900, Brazil. Tel: 55-3199-3375-932. E-mail: rodrigoagroufv@gmail.com
}

Received: August 23, 2018

Accepted: September 23, 2018

Online Published: December 15, 2018

doi:10.5539/jas.v11n1p418

URL: https://doi.org/10.5539/jas.v11n1p418

\begin{abstract}
The objective of this study was to investigate the effect of maize rhizosphere in the dynamics of soil organic matter (SOM) fractions (particulate organic matter-POM and mineral associated organic matter-MAOM) under different soil nitrogen $(\mathrm{N})$ availability. The experiment was laid out as a factorial scheme $2 \times 2$ : (i) without (-Plant) and with maize plant (+Plant); (ii) without $(-\mathrm{N})$ and with $\mathrm{N}$ fertilization $(+\mathrm{N})$ throughout $56 \mathrm{~d}$ under greenhouse conditions. Soil surface $\mathrm{CO}_{2}-\mathrm{C}$ efflux was monitored by static PVC chambers, and soil- and root-derived $\mathrm{CO}_{2}-\mathrm{C}$ efflux was determined using the mass-balance approach. In the absence of plants, $\mathrm{N}$ addition reduced total soil $\mathrm{CO}_{2}-\mathrm{C}$ efflux over the 56-d experiment and increased MAOM-C. This was followed by an increase of $366 \%$ in microbial biomass (MB-C), indicating a high $\mathrm{C}$ assimilation by soil microbes. In the presence of plants, there was evidence of positive rhizosphere priming effect (RPE) at 42-d after planting when $\mathrm{N}$ was applied. The new $\mathrm{C}$ input by rhizodeposition promoted an increase of $495 \%$ and $50 \%$ in MB-C under $-\mathrm{N}$ and $+\mathrm{N}$ addition, respectively. The short-term effect of maize rhizosphere appeared to preserve native SOM and allowed higher incorporation of microbial residues-derived C into the MAOM.
\end{abstract}

Keywords: rhizosphere priming effect, microbial mining, microbial metabolism, mineral associated organic matter-C and $\mathrm{N}, \mathrm{CO}_{2^{-}}{ }^{13} \mathrm{C}$

\section{Introduction}

The steady rise on atmospheric $\mathrm{CO}_{2}$ concentrations since the Industrial Revolution has driven the development of several studies focusing on soil management practices to increase soil organic carbon (SOC) storage (IPCC, 2014; Arneth et al., 2017). Terrestrial $C$ sequestration in soil organic matter (SOM) can be achieved when there is a positive $\mathrm{C}$ balance in the soil especially in the mineral associated-organic matter (MAOM). This is because the SOC pool within the MAOM fraction is thought to be protected by close interactions with soil minerals. Although the MAOM is often reffered to as the most 'stable' fraction, evidence is growing that even this pool of SOC can be impacted by root growth, nutrient availability and soil management (e.g., soil tillage) may increase the release of $\mathrm{CO}_{2}$ from the soil due to SOM mineralization.

Nutrient availability (e.g., $\mathrm{N}$ fertilization) in soil may affect the SOM by changing microorganisms carbon-use efficiency (CUE), that is, the amount of $\mathrm{C}$ incorporated into new biomass relative to the total $\mathrm{C}$ uptake (Manzoni et al., 2012; Cotrufo et al., 2013; Bingham \& Cotrufo, 2016) and exo-enzymes production (Drake et al., 2013). Although the effects of $\mathrm{N}$ addition SOM fractions are well-documented in several studies, divergent results have been reported. On one hand, some studies have shown positive effects of $\mathrm{N}$ addition by reducing SOM decomposition (Craine et al., 2007; Kumar et al., 2016; Zang et al., 2017; Di Lonardo et al., 2017; Liu et al., 2017; Meier et al., 2017).

In cultivated soils, rhizosphere processes may drive many complex soil-microbial biomass-plant interactions that can ultimately decrease (Thurgood et al., 2014) or increase (Shahzad et al., 2015) SOM decomposition rates. One of the main mechanisms related to changes in SOM decomposition rates is the rhizosphere priming effect (RPE), which can rise due to competition between roots and microorganisms for nutrients, particularly $\mathrm{N}$ (Kuzyakov \& Xu, 2013). The intensity of the RPE can be related to the amount and diversity of biochemical compounds produced by roots as the plants grow. As a result, relative to the root-free zone, the rhizosphere can host up to 30 -fold more microbial activity (Kuzyakov, 2002). Besides promoting many plant-microbe 
interactions, the rhizosphere also has an important role in SOC dynamics since much microbial byproducts are incorporated into MAOM fraction (Cotrufo et al., 2013; 2015). Although many efforts have been directed towards the study of $\mathrm{N}$ effects on the RPE per se (Kumar et al., 2016; Liu et al., 2017; Zang et al., 2017; Meier et al., 2017; Murphy et al., 2017), few studies have addressed the impact of both RPE and N fertilization on SOM fractions.Thus, the understanding on how rhizosphere processes can affect SOM fractions under different $\mathrm{N}$ availability conditions (e.g., fertilization management) is essential for the development of sustainable management practices, aiming to favor SOC sequestration and an efficient $\mathrm{N}$ management in agroecosystems.

The objective of this study was to investigate the impact of maize rhizosphere in SOM fractions (Particulate organic matter-POM and MAOM) under different soil $\mathrm{N}$ availability in a short-term experiment (56-d) greenhouse experiment. Thus, we hypothesized that (i) $\mathrm{N}$ fertilization should reduce the decomposition of SOM fractions in unplanted soils; (ii) low N availability in maize-planted soil should increase RPE stimulated by the demand of the plants for $\mathrm{N}$ and (iii) $\mathrm{N}$ fertilization should reduce the decomposition rate of SOM fractions in maize-planted soil.

\section{Material and Methods}

\subsection{Greenhouse Pot Experiment Design}

In this research, maize plants (Zea mays) were cultivated over 56 days under greenhouse conditions. The soil used in the experiment is classified as an Oxisol (Soil Survey Staff, 2014) showing the following properties; $\mathrm{pH}_{\mathrm{H} 2 \mathrm{O}}$ [ratio 1:2,5]: 4.76; $\mathrm{Ca}^{2+}: 18.00 \mathrm{mmol}_{\mathrm{c}} \mathrm{dm}^{-3} ; \mathrm{Mg}^{2+}: 1.20 \mathrm{mmol}_{\mathrm{c}} \mathrm{dm}^{-3} ; \mathrm{Al}^{3+}: 14.00 \mathrm{mmol}_{\mathrm{c}} \mathrm{dm}^{-3} ; \mathrm{Fe}: 69.4 \mathrm{mg} \mathrm{dm}$; CEC: $126.00 \mathrm{mmol}_{\mathrm{c}} \mathrm{dm}^{-3}$; Particulate organic matter C (POM-C): $3.40 \mathrm{mg}$ g soil ${ }^{-1}$; POM-C:N ratio: 21.86; POM- $\delta^{13} \mathrm{C}$ : $-24.79 \%$; Mineral-associated organic matter C (MAOM-C): $28.84 \mathrm{mg} \mathrm{g}^{2}$ soil $^{-1}$; MAOM-C:N ratio: 13.09; MAOM- $\delta^{13} \mathrm{C}$ : $-23.55 \%$; Clay: $81.00 \%$; Silt: $8.00 \%$ and Sand: $11.00 \%$ ). For the experiment, soil samples were collected within 0-20 cm layer of the topsoil in the central region of Minas Gerais State, Brazil $\left(19^{\circ} 28^{\prime} 4^{\prime \prime} \mathrm{S}\right.$ and $44^{\circ} 14^{\prime} 52^{\prime \prime} \mathrm{W}$; and altitude of $751 \mathrm{~m}$ above the sea level).

After collecting the samples, the soil material was air-dried, sieved (2-mm-mesh) and soil acidity corrected through liming application $\left(\mathrm{CaCO}_{3}\right.$ and $\mathrm{MgCO}_{3}$ p.a. [4:1 molar ratio]), approximately $30-\mathrm{d}$ before maize planting. The $\mathrm{C}$ present in the liming was not considered in our calculations of soil respiration since $62-74 \%$ of the $\mathrm{CO}_{2}$ originated from the reaction of carbonates in acid soil should have been released within the first 14-d following its application (Ramnarine et al., 2012). Besides, liming was applied in all treatments.

The fertilization of the soil was done using a nutrient solution (Novais, 1991), from which we added $\mathrm{P}$ at $300.0 \mathrm{mg}$ $\mathrm{kg} \mathrm{soil}^{-1}, \mathrm{~K}$ at $150.0 \mathrm{mg} \mathrm{kg} \mathrm{soil}{ }^{-1} ; \mathrm{S}$ at $40.0 \mathrm{mg} \mathrm{kg} \mathrm{soil}^{-1} ; \mathrm{B}$ at $0.81 \mathrm{mg} \mathrm{kg} \mathrm{soil}{ }^{-1} ; \mathrm{Cu}$ at $1.33 \mathrm{mg} \mathrm{kg} \mathrm{soil}{ }^{-1} ; \mathrm{Mn}$ at 3.66 $\mathrm{mg} \mathrm{kg} \mathrm{soil}{ }^{-1}$; Mo at $0.15 \mathrm{mg} \mathrm{kg} \mathrm{soil}^{-1}$; and $\mathrm{Zn}$ at $4.0 \mathrm{mg} \mathrm{kg} \mathrm{soil}^{-1}$. Afterwards, the soil $\left(7-\mathrm{dm}^{3}\right)$ was accommodated in plastic pots $\left(8-\mathrm{dm}^{3}\right)$ and wetted to $80 \%$ of field capacity.

The experiment was set according to randomized block design with three replications arranged in a factorial scheme $2 \times 2$ including (i) pots without maize plants (-Plant) and pots with maize plants (+Plant); (ii) pots without nitrogen application $(-\mathrm{N})$ and pots with with nitrogen application $\left(100 \mathrm{mg} \mathrm{N} \mathrm{dm}^{-3}\right.$ applied via $\mathrm{NH}_{4} \mathrm{NO}_{3}$ solution. Six maize seeds (DKB 390 hybrid) were planted and after germination and thinning, three plants per pot were grown until the V8 stage (56-d after planting). Irrigation was performed daily in order to maintain soil moisture at $60 \%$ of field capacity.

\subsection{Soil Surface $\mathrm{CO}_{2}-\mathrm{C}$ Effluxes}

Soil surface $\mathrm{CO}_{2}-\mathrm{C}$ efflux was monitored by static PVC chambers $(7.5 \times 10.0-\mathrm{cm})$ installed in all pots. The chambers were fitted with removable caps including a rubber septum to allow sampling the gases evolved from the soil. The gas released from the soil was collected using plastic syringes $(60-\mathrm{mL})$ at $0,10,20$ and 40 -min at 0 , 7, 14, 21, 28, 35, 42, 49 and 56-d after planting. The gas samples collected were analyzed in a Cavity Ring-Down Spectrometer (CRDS, G2131-i, Picarro, Sunnyvale, $\mathrm{CA}$ ) for $\mathrm{CO}_{2}-\mathrm{C}(\mathrm{ppm})$ and $\mathrm{CO}_{2}-{ }^{13} \mathrm{C}$ (expressed in \%o) relative to the Vienna PDB standard. Total soil $\mathrm{CO}_{2}-\mathrm{C}$ effluxes were calculated using the Equation (1) according to Smith and Conen (2004) and adapted by Oliveira et al. (2017), as follows:

$$
\text { Soil surface } \mathrm{CO}_{2}-\mathrm{C}=[(\Delta Q / \Delta t) \times M \times P \times V] / R \times T \times A
$$

where, Soil surface $\mathrm{CO}_{2}-\mathrm{C}$ is the total $\mathrm{CO}_{2}$ evolved from soil $\left(\mu \mathrm{g} \mathrm{m}^{-2} \mathrm{~h}^{-1}\right) ; \Delta Q / \Delta t$ is the variation in $\mathrm{CO}_{2}-\mathrm{C}$ concentration over time; $M$ is the molar mass of $\mathrm{C} ; P$ is the pressure inside the chamber, assumed to be 1 atmosphere (atm); $V$ is the chamber volume (L); $R$ is the universal gas constant $\left(0.0821 \mathrm{~L} \mathrm{~atm} \mathrm{~K}^{-1} \mathrm{~mol}^{-1}\right)$; $T$ is the temperature of the atmosphere $(\mathrm{K})$ and $A$ is the chamber area $\left(\mathrm{m}^{2}\right)$. 
Subsequently, we used the Keeling plot method (Keeling, 1958) to determine the $\mathrm{CO}_{2}-\delta^{13} \mathrm{C}$ of the total soil surface $\mathrm{CO}_{2}$-C fluxes. Since the soil used was under a $\mathrm{C}_{3}$ vegetation and the maize is a $\mathrm{C}_{4}$ plant, it was possible to partition the soil surface $\mathrm{CO}_{2}-\mathrm{C}$ efflux in soil and root-derived $\mathrm{CO}_{2}-\mathrm{C}$ efflux using the mass balance approach according to the Equation (2)-to-(4), as follows:

$$
\begin{gathered}
R_{\text {total }}=R_{\text {soil }}+R_{\text {roots }} \\
R_{\text {total }} \times A_{\text {total }}{ }^{13}=R_{\text {soil }} \times A_{\text {soil }}{ }^{13}+R_{\text {roots }} \times A_{\text {roots }}{ }^{13} \\
R_{\text {soil }}=R_{\text {total }} \times\left(A_{\text {total }}{ }^{13}-A_{\text {roots }}{ }^{13}\right) /\left(A_{\text {soil }}{ }^{13}-A_{\text {roots }}{ }^{2}\right)
\end{gathered}
$$

where, $R_{\text {total }}$ : soil surface $\mathrm{CO}_{2}-\mathrm{C}$ efflux $\left(\mu \mathrm{g} \mathrm{m} \mathrm{m}^{-2} \mathrm{~h}^{-1}\right) ; R_{\text {soil }}$ : soil-derived $\mathrm{CO}_{2}-\mathrm{C}$ efflux $\left(\mu \mathrm{g} \mathrm{m}^{-2} \mathrm{~h}^{-1}\right) ; R_{\text {roots }}$ : root-derived $\mathrm{CO}_{2}-\mathrm{C}$ efflux $\left(\mu \mathrm{g} \mathrm{m}{ }^{-2} \mathrm{~h}^{-1}\right) ; A_{\text {soil }}{ }^{13}$ : soil surface $\mathrm{CO}_{2}-\delta^{13} \mathrm{C}$ efflux $(\%) ; A_{\text {roots }}^{13}$ : the root biomass- $\delta^{13} \mathrm{C}$ (-13.04\%, determined after harvesting the maize plants by using an element analyzer coupled to a mass spectrometer of isotopic ratio-IRMS [GSL 20-20 HIP, Sercon, Crewe, UK]).

Rhizosphere priming effect (RPE) induced by maize plants throughout the period of the experiment was calculated using Equation (5):

$$
R P E=\left[\left(R_{\text {soil }} \text { cultivated soil }-R_{\text {soil }} \text { uncultivated soil }\right) / R_{\text {soil }} \text { uncultivated soil }\right] \times 100
$$

where, $R P E$ : rhizosphere priming effect (\%); $R_{\text {soil }}$ cultivated soil: soil-derived $\mathrm{CO}_{2}-\mathrm{C}$ efflux $\left(\mu \mathrm{g} \mathrm{m}^{-2} \mathrm{~h}^{-1}\right)$ in soil cultivated with maize (+Plant $-\mathrm{N}$ and + Plant $+\mathrm{N}) ; R_{\text {soil }}$ uncultivated soil: soil-derived $\mathrm{CO}_{2}-\mathrm{C}$ efflux $\left(\mu \mathrm{g} \mathrm{m}^{-2} \mathrm{~h}^{-1}\right)$ in soil uncultivated with maize (-Plant -N).

\subsection{Plant Analyses}

After the 56-d experiment, maize plants were harvested, roots were separated from the shoots and washed in deionized water. Subsequently, the plant material was dried in an oven at $65{ }^{\circ} \mathrm{C}$ for 72 -h, weighed and milled. We used element analyzer coupled to a mass spectrometer of isotopic ratio-IRMS (GSL 20-20 HIP, Sercon, Crewe, UK) to etermine total $\mathrm{C}, \delta^{13} \mathrm{C}$ and $\mathrm{N}$ in the roots and shoots.

\subsection{Microbiological Analyses and Parameters}

Soils samples (5-g fresh soil) were taken at the end of the experiment for biomass microbial-C determination (MB-C) using the microwave irradiation-incubation method (Islam, 1998). Irradiated and non-irradiated soil samples were incubated $\left(25 \pm 1{ }^{\circ} \mathrm{C}\right.$, in the dark) for 10-days in glass pots $(0.25-\mathrm{L})$ after being "inoculated" with non-irradiated subsamples $(0.1-\mathrm{g})$. The $\mathrm{CO}_{2}-\mathrm{C}$ released $(\mathrm{ppm})$ and $\mathrm{CO}_{2}-\delta^{13} \mathrm{C}(\%)$ of the incubated samples $(0,3$, 6 and 10-d) were determined by the Cavity Ring-Down Spectrometer (CRDS, G2131-i, Picarro, Sunnyvale, CA). The MB-C was calculated following the Equation (6):

$$
\mathrm{MB}-\mathrm{C}=\left[\left(\mathrm{CO}_{2}-\mathrm{C}_{\mathrm{I}}-\mathrm{CO}_{2}-\mathrm{C}_{\mathrm{NI}}\right) / \mathrm{K}_{\mathrm{C}}\right]=\mathrm{Fc} / \mathrm{Kc}
$$

where, $\mathrm{Fc}$ is the $\mathrm{CO}_{2}-\mathrm{C}$ release in irradiated soil minus the $\mathrm{CO}_{2}-\mathrm{C}$ release in non-irradiated soil; $K c$ is the fraction (0.45) of MB-C mineralized as $\mathrm{CO}_{2}-\mathrm{C}$ for 10-d as determined by Jenkison and Powlson (1976).

Root-derived microbial biomass C (MB-RDC) was calculated (Equation 7) through the same approach previously described in the Equations (2)-to-(4).

$$
M B-R D C=\left[\left(C O_{2}-R D C_{I}-C O_{2}-R D C_{N I}\right) / k_{C}\right]=D R F c / K c
$$

where $R D C_{C}$ is the root-derived $\mathrm{CO}_{2}-\mathrm{C}$ release in irradiated soil minus the root-derived $\mathrm{CO}_{2}-\mathrm{C}$ release in non-irradiated soil.

The metabolic quotient $\left(\mathrm{qCO}_{2}\right)$ was calculated as a proxy for the CUE 56-d after the maize growth, which refers to the ratio of the respiration rate $\left(\mathrm{CO}_{2}-\mathrm{C}_{\mathrm{Rate}}\right)$ per unit of biomass (Dilly \& Munch, 1998), following the Equation (8):

$$
q \mathrm{CO}_{2}=\left(\mathrm{CO}_{2}-\mathrm{C}_{\text {Rate }} / C-B M S\right)
$$

where, $\mathrm{CO}_{2}-\mathrm{C}_{\text {Rate }}$ : the total cumulative $\mathrm{CO}_{2}$-C divided by 10 -d.

\subsection{Soil Analysis}

Soil samples were collected in each plastic pot at the end of the experiment and physical fractionation to obtain SOM fractions was performed according to Cambardella and Elliott (1992). Shortly, 10-g of soil was dispersed in $30 \mathrm{~mL}$ of sodium hexametaphosphate $\left(5 \mathrm{~g} \mathrm{~L}^{-1}\right)$ into $50-\mathrm{mL}$ centrifuge tubes using glass beads and continuos shaking for $15 \mathrm{~h}$ in a horizontal shaker $(120 \mathrm{rpm})$. After dispersion, SOM fractions were obtained by wet-sieving using a $0.053-\mathrm{mm}$-mesh sieve. The material retained on the sieve is defined as particulate organic matter (POM), while the soil slurry that passed through the sieve is defined as mineral associated organic matter (MAOM). Both 
materials were properly separated and dried in an oven at $60{ }^{\circ} \mathrm{C}$ for $7 \mathrm{~d}$. Subsequently, both fractions were weighted and ground $(<149 \mathrm{~mm})$ using a ball mill. Subsamples from both fractions were taken for total $\mathrm{C}, \mathrm{N}$ and $\delta^{13} \mathrm{C}$ determination using an Isotopic Ratio Mass Spectrometer-IRMS (GSL 20-20 HIP, Sercon, Crewe, UK). Root-derived C in both SOM fractions was calculated using the same mass balance approach described in the Equations (2)-to-(4).

\subsection{Statistical Analyses}

The data were subjected to two-away ANOVA. The $\mathrm{CO}_{2}-\mathrm{C}$ efflux, priming effect, MB-RDC, Root, Shoot, Root: Shoot, Root-C: N and Shoot-C: $\mathrm{N}$ of maize plant were compared using the F's test; and $\mathrm{MB}-\mathrm{C}, \mathrm{CO}_{2}-\mathrm{C}$ rate, $\mathrm{qCO}_{2}$, POM-C, POM-C:N, MAOM-C and MAOM-C:N were compared using the Tukey's test $(p<0.05)$. Statistical analyses were performed using the $\operatorname{SISVAR}^{\circledR}$ software (Ferreira, 2011).

\section{Results}

\subsection{Maize Growing and Soil Surface $\mathrm{CO}_{2}-\mathrm{C}$ Efflux}

Throughout the period of the experiment, growing maize plants led to an increase in total $\mathrm{CO}_{2}-\mathrm{C}$ efflux, except at 56-d for the treatments receing $\mathrm{N}$ fertilization (Figure 1a). Otherwise, the soil without plants (either -Plant - $\mathrm{N}$ or - Plant $+\mathrm{N}$ ) showed the lowest total $\mathrm{CO}_{2}-\mathrm{C}$ effluxes over time.

Total $\mathrm{CO}_{2}-\mathrm{C}$ efflux components (Soil-derived $\mathrm{CO}_{2}-\mathrm{C}$ efflux and Root-derived $\mathrm{CO}_{2}-\mathrm{C}$ ) were altered by $\mathrm{N}$ application during maize growth (Figures $1 \mathrm{~b}-1 \mathrm{c}$ ). Nitrogen application promoted the inhibition of $711 \mu \mathrm{g} \mathrm{m}^{-2} \mathrm{~h}^{-1}$ in soil-derived $\mathrm{CO}_{2}-\mathrm{C}$ efflux up to 7-d after beginning the experiment $(p<0.01)$ (Figure 1b). Further differences were observed around 36-d and 49-d, when the $-\mathrm{N}$ and $+\mathrm{N}$ treatments led to higher soil-derived $\mathrm{CO}_{2}-\mathrm{C}$ efflux, respectively (Figure 1b). At 42-d after planting onwards, root-derived $\mathrm{CO}_{2}-\mathrm{C}$ for the $-\mathrm{N}$ treatments was higher (49-d: $402 \mu \mathrm{g} \mathrm{m}^{-2} \mathrm{~h}^{-1} ; p<0.01$ and 56-d: $773 \mu \mathrm{g} \mathrm{m}^{-2} \mathrm{~h}^{-1} ; p<0.01$ ) than when $\mathrm{N}$ was applied (Figure 1c). Otherwise, at 49-d after planting the addition of nitrogen resulted in an increase of $483 \mu \mathrm{g} \mathrm{m}^{-2} \mathrm{~h}^{-1}(p \leq 0.01)$ in soil-derived $\mathrm{CO}_{2}$-C efflux (Figure 1b).

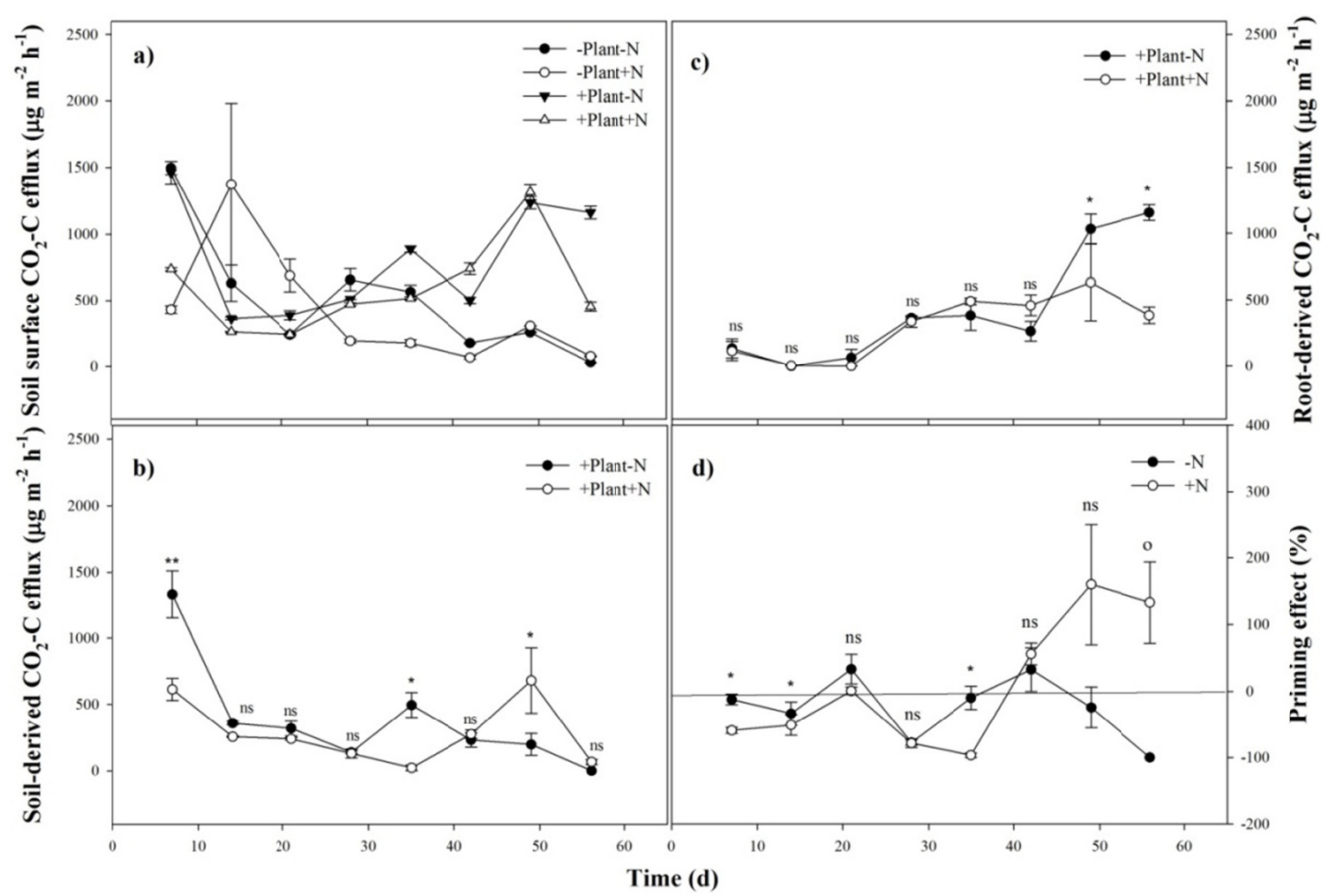

Figure 1. Soil surface $\mathrm{CO}_{2}-\mathrm{C}$ efflux $\left(\mathrm{a} ; \mu \mathrm{g} \mathrm{m}^{-2} \mathrm{~h}^{-1}\right)$, Soil-derived $\mathrm{CO}_{2}-\mathrm{C}$ efflux $\left(\mathrm{b} ; \mu \mathrm{g} \mathrm{m}^{-2} \mathrm{~h}^{-1}\right.$ ), Root-derived

$\mathrm{CO}_{2}-\mathrm{C}$ efflux (c; $\left.\mu \mathrm{g} \mathrm{m}^{-2} \mathrm{~h}^{-1}\right)$ and Priming effect $(\mathrm{d}$; \%) over the maize growing $(7,14,21,28,35,42,49$ and 56 days after planting) without $(-\mathrm{N})$ and with $(+\mathrm{N})$ nitrogen application $\left(100 \mathrm{mg} \mathrm{dm}^{-3}\right)$.

${ }^{* *},{ }^{*}$ significant effects at $p<0.01$ and $p<0.05$, respectively. ${ }^{\mathrm{ns}}$ not significant by $\mathrm{F}$ test. Vertical bars denote the standard error of the mean $(n=3)$ 
Estimates of RPE ranged between $400 \%$ when maize plants were fertilized with $\mathrm{N}$ to $100 \%$ for the treatments without $\mathrm{N}$ supply (Figure 1d). However, no significant differences were observed between $-\mathrm{N}$ and $+\mathrm{N}$, except after 42-d, when more SOC was primed in the presence of nitrogen application $(347 \% ; p<0.01)$ (Figure 1d).

\subsection{Soil Microbial Biomass and Microbial Parameters}

For the treatments including maize plants (56-d after planting) there was an increase in soil microbial biomass relative to the the treatments without plants. However, the relative increase in microbial biomass was up to $494 \%$ in the absence of $\mathrm{N}$ fertilization and only $50 \%$ when the nutrient was added $(p<0.01$ and $+\mathrm{N}: 50 \% ; p<0.01)$ (Figure 2a). We also observed that $\mathrm{N}$ application itself affected positively soil microbial biomass, but only in the absence of maize plants. As such, relative to the $-\mathrm{N}$ treatment without plants, the relative increase in microbial biomass was 366\% ( $p<0.01)$, and only $18 \%$ when in the presence of plants $(p<0.05)$ (Figure 2a). Besides, in the presence of plants, there were no differences for the icorporation of root-derived $\mathrm{C}$ by soil microbial biomass (RDC-MB; \%) in response to nitrogen application $(p=0.06)$ (Figure $2 \mathrm{~b}$ ).

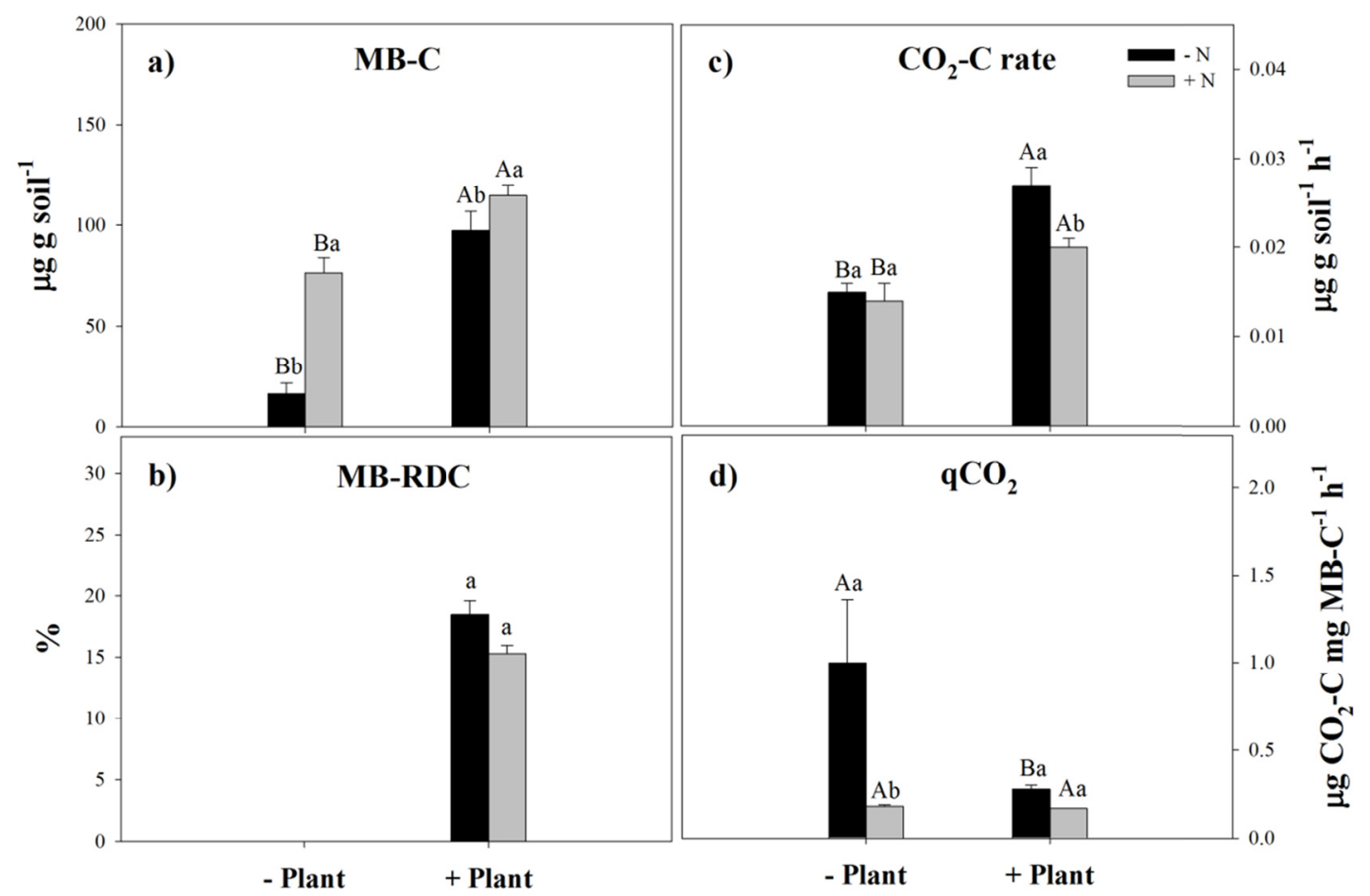

Figure 2. Microbial biomass carbon (MB-C; $\left.\mu \mathrm{g} \mathrm{g} \mathrm{g}^{-1}\right), \mathrm{CO}_{2}-\mathrm{C}$ rate $\left(\mu \mathrm{g} \mathrm{g}^{-1} \mathrm{~h}^{-1}\right)$ and Metabolic quotient $\left(\mathrm{qCO}_{2} ; \mu \mathrm{g}\right.$

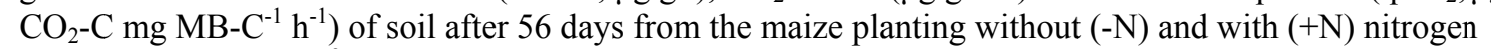
application $\left(100 \mathrm{mg} \mathrm{dm}^{-3}\right)$. Vertical bars denote the standard error of the mean $(\mathrm{n}=3)$. Significant differences between plants are indicated by different capital letters, while significant differences between $-\mathrm{N}$ and $+\mathrm{N}$ are indicated by different lowercase letter (Tukey's test; $p<0.05$ )

Maize growth also increased the total $\mathrm{CO}_{2}-\mathrm{C}$ released during the $56-\mathrm{d}$ experiment $(-\mathrm{N}: 80 \% ; p<0.01 ;+\mathrm{N}: 42.8 \%$; $p<0.05$ ) (Figure 2c). On the other hand, nitrogen application reduced the $\mathrm{CO}_{2}-\mathrm{C}$ release rate in the presence of plants during the same period $\left(0.007 \mu \mathrm{g} \mathrm{g}^{-1} \mathrm{~h}^{-1} ; p<0.01\right)$ (Figure $2 \mathrm{c}$ ). Microbial growth in the presence of maize plants had the smallest $\mathrm{qCO}_{2}$ independently of the $\mathrm{N}$ fertilization $(p<0.05)$, while in the absence of maize plants the $\mathrm{N}$ addition reduced the $\mathrm{qCO}_{2}(82 \% ; p<0.01)$ (Figure 2d).

\subsection{Maize Dry Matter, $C$ and $N$}

After 56-d, there were no differences due to nitrogen application in the dry matter of root $(p=0.43)$, shoot ( $p=$ $0.09)$ and root:shoot ratio $(p=0.21)$. However, nitrogen application increased $\mathrm{N}$ incorporation into the biomass of both root (root-C:N; $p<0.05$ ) and shoot (Shoot-C:N; $p<0.01$ ) (Table 1). Nitrogen uptake by maize plants under $\mathrm{N}$ application was $1.05 \mathrm{~g} \mathrm{pot}^{-1}$ higher than without $\mathrm{N}$ application $(p<0.01$; Table 1$)$. 
Table 1. Root (g), shoot (g), root:shoot ratio, and C:N ratios of root shoot of maize plants after 56 day of growth without $(-\mathrm{N})$ and with $(+\mathrm{N})$ nitrogen application $\left(100 \mathrm{mg} \mathrm{dm}^{-3}\right)$

\begin{tabular}{lll}
\hline & $-\mathrm{N}$ & $+\mathrm{N}$ \\
\hline Root $(\mathrm{g})$ & $71.16( \pm 0.59)$ & $59.45( \pm 4.13)^{\mathrm{ns}}$ \\
Shoot $(\mathrm{g})$ & $110.00( \pm 2.88)$ & $123.00( \pm 10.39)^{\mathrm{o}}$ \\
Root:Shoot & $0.64( \pm 0.01)$ & $0.55( \pm 0.04)^{\mathrm{ns}}$ \\
Root-C:N & $52.25( \pm 3.95)$ & $28.60( \pm 0.20)^{*}$ \\
Shoot-C:N & $47.67( \pm 1.66)$ & $29.01( \pm 0.84)^{* *}$ \\
Total N plant $\left(\mathrm{g} \mathrm{pot}^{-1}\right)$ & $1.71( \pm 0.07)$ & $2.76( \pm 0.05)^{* *}$ \\
\hline
\end{tabular}

Note. ${ }^{* *},{ }^{*},{ }^{0}$ significant effects at $p<0.01, p<0.05$ and $p<0.10$, respectively. ${ }^{\text {ns }}$ not significant by $\mathrm{F}$ test. Vertical bars denote the standard error of the mean $(n=3)$.

\subsection{Soil Organic Matter Fractions}

Both SOM fractions have changed upon maize grow and nitrogen application. No differences were detectable in POM-C under maize (-N: $p=0.10$ and $+\mathrm{N}: p=0.58)$ or nitrogen application (-Plant: $p=0.09$ and +Plant: $p=$ 0.53 ) (Figure 3 ). The effect of nitrogen application was only observed in the soil without maize plants, where there was a preservation of $10.8 \%$ in the MAOM-C relative to the treatments with plants $(p<0.01)$.

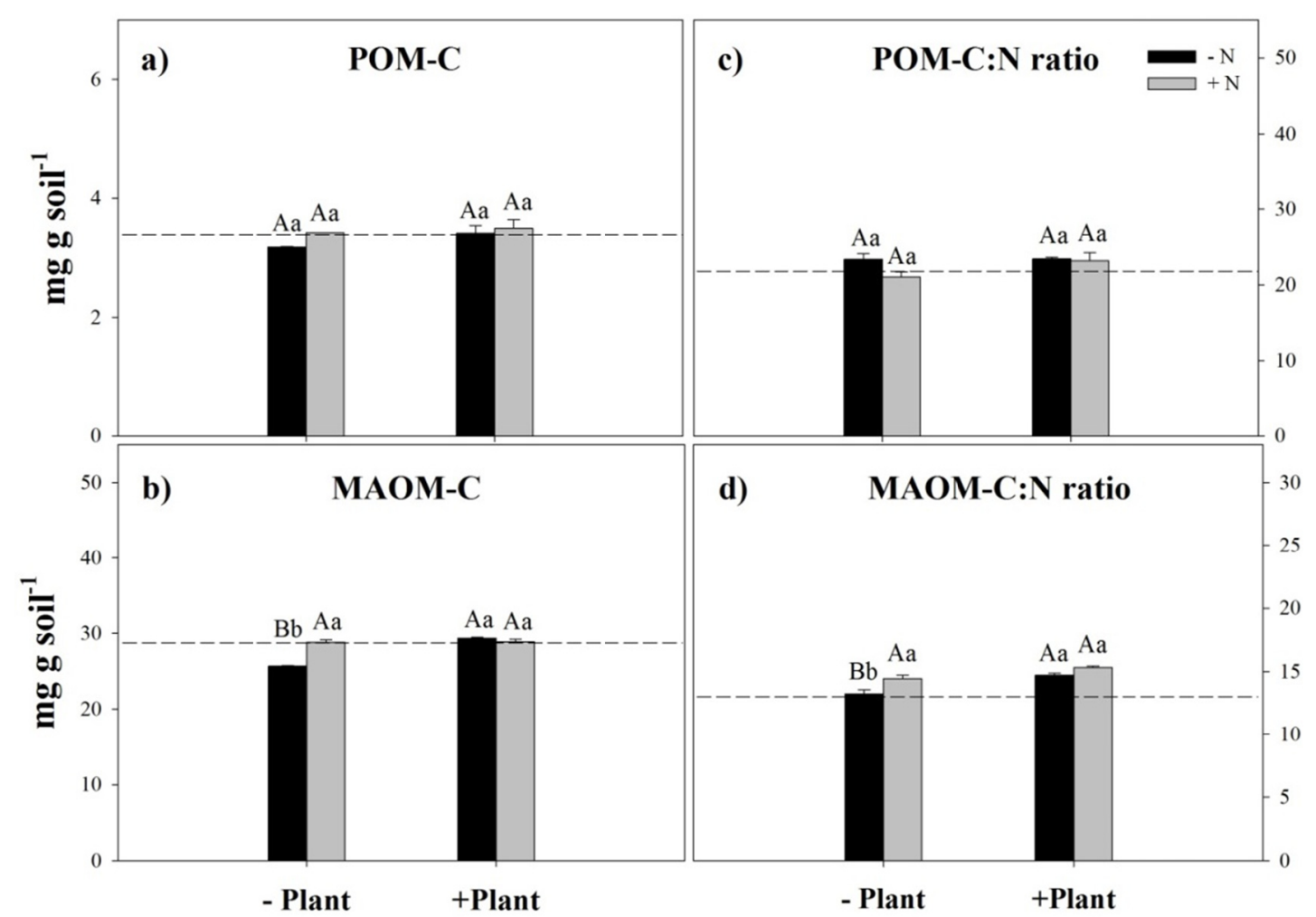

Figure 3. Particulate Organic Matter-POM-C $\left(\mathrm{mg} \mathrm{g}\right.$ soil $\left.^{-1}\right)$, Mineral Associated-Organic Matter-MAOM-C (mg g soil ${ }^{-1}$ ), POM-C:N ratio and MAOM-C:N ratio of soil after 56 days from the maize planting without (-N) and with $(+\mathrm{N})$ nitrogen application $\left(100 \mathrm{mg} \mathrm{dm}^{-3}\right)$. Vertical bars denote the standard error of the mean $(\mathrm{n}=3)$. Significant differences between plants are indicated by different capital letters, while significant differences between $-\mathrm{N}$ and $+\mathrm{N}$ are indicated by different lowercase letter (Tukey's test; $p<0.05$ )

No differences were observed for $\mathrm{N}$ incorporated in the POM (POM-C:N). Changes in the MAOM fraction were only observed in the absence of plants and nitrogen fertilization, which the average of $\mathrm{N}$ loss was $8.4 \%$ (Figure $3)$. 


\section{Discussions}

\subsection{Influence of N Addition in SOM Fractions Decomposition}

Biological processes that regulate the $\mathrm{C}$ cycle in soil are strongly related with nutrients availability and energy demand by soil microbes. In our study, it was observed a fast decrease of total soil surface and soil-derived $\mathrm{CO}_{2}$-C efflux by $\mathrm{N}$ addition (7-d; Figure 1a). The same pattern has been well-documented in other studies for both short- (Kumar et al., 2016; Rinkes et al., 2016; Zang et al., 2017; Fang et al., 2018) and long-term experiments (Chen et al., 2016; Riggs \& Hobbie, 2016; Ward et al., 2017).

Reductions in soil respiration rates by $\mathrm{N}$ addition are mainly related to: (i) slow microbial growth stimulated by acidification promoted by $\mathrm{N}$ addition (Chen et al., 2016; Averill et al., 2017); (ii) improvement of CUE (Manzoni et al., 2012; Manzoni, 2017); (iii) reduced production of SOM-degrading enzymes to obtain $\mathrm{N}$ from soil organic compounds (Fontaine et al., 2011; Kumar et al., 2016; Rinkes et al., 2016). Therefore, increases in soil respiration can be inferred from $\mathrm{qCO}_{2}$, which represents an overflow metabolism that occurs when microbes still take up $\mathrm{C}$, but enough not nitrogen. In this process, the metabolism is decoupled from growth and total respiration relative to unit of biomass increases (Schimel \& Weintraub, 2003). In our study, the $\mathrm{qCO}_{2}$ decreased with $\mathrm{N}$ addition after 56-d (Figure 2d), which indicates high CUE. Thus, according to the "Stoichiometric decomposition theory", mineral $\mathrm{N}$ availability favors the decomposition of $\mathrm{N}$-poor compounds and enzymes production that degrades $\mathrm{N}$ through mining SOM fractions (Craine et al., 2007). In addition, this fact reduces the extra energy cost associated with extracellular enzymes production and $\mathrm{C}$ substrate investment in catabolic process (e.g. maintenance respiration), favoring the higher CUE (Manzoni, 2012). Relative to the non-fertilized treatments, total respiration was and microbial biomass were greater in the presence of $\mathrm{N}$ and for these reasons, there were also greater basal and growth respiration of living microorganisms (Schimel \& Weintraub, 2003).

The induction of a specific uptake system to excavenge the environment for the nutrient mechanism could explain the reason of the lower stability of the MOAM fraction under restricted nitrogen availability since a greater exoenzymes production can depolymerize more amount of soil organic matter Our results suggests that soil microbes are capable of mine SOM, particularly when N availability is low (Schimel \& Weintraub, 2003). However, no evidence for changes in oxidative or hydrolytic enzymes were observed in long-term experiment (7 years) in response to $\mathrm{N}$ addition levels (Riggs and Hobbie, 2016). Similarly, no changes in $\beta-1,4$-glucosidase and L-leucine aminopeptidase activities in unplanted soils were observed after 50-d of $\mathrm{N}$ addition (short-term experiment) in a field incubation experiment (Kumar et al., 2016). In contrast, Rinkes et al. (2016) studying the decomposition of maize straw in a 478-d laboratory incubation showed that $\mathrm{N}$ addition suppressed the activity of lignin-degrading enzymes.

Finally, the higher CUE caused by N addition alleviated the decomposition of the MAOM fraction (Figure 3b), but no shifts were observed in labile fractions (POM-C; Figure 3a). Currently, studies have proposed the natural decomposition pathway from POM to MAOM (Mazzilli et al., 2014; Averill \& Waring, 2017). However, in relation to the "Carbon, Acidity and Mineral Protection (CAMP) hypothesis" proposed by Averill and Waring (2017), the increase in CUE and biomass turnover rate promotes enhance in MAOM-C by microbial residue-derived $\mathrm{C}$ input. The higher MAOM-C in unplanted soil in the presence of $\mathrm{N}$ addition than unplanted soil without $\mathrm{N}$ addition, suggests that a preservation of native MAOM-C has been detected in short-term (54-d) with undetectable alterations in POM-C, and/or microbial turnover with incorporation of microbial residues-derived $\mathrm{C}$ to MAOM.

The degradation of MAOM rather than POM in unplanted soil with N limitation (10.8\%) can be understood by a conceptual model of organo-mineral interactions, proposed by Kleber et al. (2007). According to these authors, the retention of MAOM-C is due to (i) an inner-layer of strong organo-mineral associations formed through ligand exchange; (ii) a protected-layer of hydrophobic interactions and (iii) a 'kinetic zone' where organic molecules have high exchange rates with surrounding soil solution. Therefore, it is possible that under $\mathrm{N}$ limitation soil microbes can overcome mineral protection to obtain $\mathrm{N}$.

\subsection{Influence of Soil N Availability-Maize Growth Interactions in SOM Fractions Decomposition}

Soil $\mathrm{N}$ availability influences plant-microbial interactions, altering $\mathrm{C}$ and $\mathrm{N}$ balance in the rhizosphere (Kuzyakov \& $\mathrm{Xu}$, 2013). In our study, it was observed alteration on total soil surface $\mathrm{CO}_{2}$-C efflux following maize growth (Figures 1a-1c). The earlier effects of $\mathrm{N}$ addition in microbial activity were detected at 7-d in soil-derived $\mathrm{CO}_{2}-\mathrm{C}$ efflux as previously discussed, evidencing no great effect of $\mathrm{N}$ additions over maize growth until 56-d (Figure 1b). This effect may indicate the presence of different mechanisms of priming effect throughout the maize growth period. At first, the presence of plants with low growth rates - primarily dependent on seed reserves - coupled with high $\mathrm{N}$ availability, may have conditioned less competition for microbial growth 
resources, resulting in low soil-derived $\mathrm{CO}_{2}$ - $\mathrm{C}$ efflux (Cheng, 1999). In the absence of $\mathrm{N}$, the microorganisms can utilize the $\mathrm{C}$ added by roots for synthetizing exoenzymes that leads to higher respiration rates of soil-derived $\mathrm{CO}_{2}-\mathrm{C}$ (Craine et al., 2007).

As plants grow, in the presence or absence of $\mathrm{N}$, increased root growth and exudation resulted in lower rates of soil-derived $\mathrm{CO}_{2}-\mathrm{C}$ compared to the beginning of the experiment. This probably promoted the breakdown of fresh organic matter, which can be verified by the absence of alteration in the POM and MOAM fractions in the presence of the plants (Cheng \& Kuzyakov, 2005).

The evident increases in root-derived $\mathrm{CO}_{2}-\mathrm{C}$ efflux observed in the soil without $\mathrm{N}$ addition after 42-d (Figure 1c), indicates high root activity, including root respiration and microbial decomposition of maize root exudates (Kraffczyk et al., 1984; Hodge et al., 1996; Kumar et al., 2016). Maize root growth would create dynamic "hotspots" in the soil (Kuzyakov \& Blagodatskaya, 2015) and the RPE may vary through the plant development as observed in the present study. Based on our results, high positive RPE occurred after 42-d of maize planting (Figure 1d). In agreement with our results, short-term increase in RPE after planting has accounted for $22.8 \%$ of the total variation of the RPE (Huo et al., 2017). Chen et al. (2014) proposed that positive priming effect may occur in low and high soil $\mathrm{N}$ availability condition. According to the 'microbial N-mining' theory, under low $\mathrm{N}$ condition k-strategists microbes are the main active decomposers of SOM. In contrast, the 'microbial stoichiometry' theory suggests that under high $\mathrm{N}$ availability r-strategists microbes are more active on SOM decomposition. Thus, in our study the 'microbial stoichiometry' theory seems to be the main mechanism underline of the positive RPE under N addition (Chowdhury et al., 2014; Di Leonardo et al., 2017; Meier et al., 2017).

At 56-d after planting, there was a trend to higher maize shoot biomass production with $\mathrm{N}$ addition than without $\mathrm{N}$ fertilization $(16 \%, \mathrm{p}=0.09$; Table 1$)$. High $\mathrm{N}$ availability may increase net assimilation and favor high shoot biomass yield (Zhu et al., 2015). Similar to our results, $\mathrm{N}$ tracer studies with $\mathrm{N}$-fertilizer addition had consistently positive effects on plant uptake of native soil $\mathrm{N}$ (Liu et al., 2017). So, possibly in $2.76 \mathrm{~g} \mathrm{pot}^{-1}$ of total $\mathrm{N}$ plant in soil with $\mathrm{N}$ addition, more native soil $\mathrm{N}$ is present than the soil without $\mathrm{N}$ addition $\left(1.71 \mathrm{~g} \mathrm{pot}^{-1}\right.$; Table 1). Furthermore, was observed in this following study that the RPE was positively and linearly correlated with plant shoot biomass across different plant species. In contrast, root biomass showed no correlation with RPE and accounted for nearly zero variation (Huo et al., 2017).

The new $\mathrm{C}$ input by rhizodeposition until 56-d of maize growth promoted an increase of $495 \%$ and $50 \%$ in MB-C to no $\mathrm{N}$ addition and $\mathrm{N}$ addition amended, respectively (Figure $2 \mathrm{a}$ ). The well-known easily degradable compounds released by root exudation likely increased microbial assimilation efficiency of soil microorganisms (Craine et al., 2007; Manzoni et al., 2012; Cotrufo et al., 2013), as verified in our study by the increase in $\mathrm{qCO}_{2}$ to no $\mathrm{N}$ addition without plant (Figure $2 \mathrm{~d}$ ).

Nonetheless, increases of only $17.8 \%$ in MB-C was observed when the maize was present under $\mathrm{N}$ addition (Figure 2a), while no differences were detectable in $\mathrm{CO}_{2}-\mathrm{C}$ rate (Figure 2c) and $\mathrm{qCO}_{2}$ (Figure 2d). This fact suggests greater influence from rhizosphere effect (rhizodeposit $\mathrm{C}$ input) in soil microbial communities than $\mathrm{N}$ availability. Microbial growth in soils appears to be energy-limited and stoichiometric imbalances-limited, strongly influencing the abundance of soil microbial communities. Soil with $\mathrm{C}$ and $\mathrm{N}$ availability is reported to have abundance of $r$-strategist microorganisms, which is in accordance with 'microbial stoichiometry' theory in our planted soil under $\mathrm{N}$ addition (Chen et al., 2014). However, slight trend is observed in the incorporation of root-derived $\mathrm{C}$ in microbial biomass (MB-RDC, $\mathrm{p}=0.06$; Figure $2 \mathrm{~b}$ ). Although no differences were observed in the $\mathrm{qCO}_{2}$ with and without $\mathrm{N}$ addition to planted soil (Figure 2d), microbial communities of planted soil and with no $\mathrm{N}$ addition seems to have a greater $\mathrm{C}$-use efficiency. This premise is according to 'microbial $\mathrm{N}$-mining' theory, which says that in low $\mathrm{N}$ availability there are abundance of fungi communities (Chen et al., 2014). So, since fungi have a higher C:N ratio than bacteria (Six et al., 2006) and the CUE, fungi tends to increase strongly with nutrient availability (Manzoni et al., 2012).

The short-term (56-d) of maize planting without $\mathrm{N}$ addition besides preserving native SOM decomposition, allowed higher microbial CUE and consequent incorporation of microbial residues-derived $\mathrm{C}$ into the MAOM (14.27\%; Figure 3b). However, in the planted soil no shifts were verified on $\mathrm{N}$ treatments, reinterating the greater effect of rhizosphere (rhizodeposit $\mathrm{C}$ input) in soil microbial communities than soil $\mathrm{N}$ availability.

Our finding presents strong evidences that short-term alterations may occur influenced by rhizosphere process with low soil $\mathrm{N}$ availability. To the best of our knowledge, this study is one of the few studies which verified increases in short-term in MAOM-C provided by rhizodepositions, besides to support the Matrix Stabilization Framework (MEMS), which proposes that more labile substrates lead to a greater contribution of $\mathrm{C}$ in soil 
mineral fraction (soil silt and clay) (Cotrufo et al., 2013; Cyle et al., 2016). We encourage further field-scale research tracking the SOM fractions (POM and MAOM) associated with isotopic and molecular techniques to investigate the short-term effect of crop rhizosphere in stable fractions of SOM.

\section{Conclusions}

In summary, our first hypothesis was confirmed since the $\mathrm{N}$ addition in unplanted soil promoted a reduction in total soil $\mathrm{CO}_{2}-\mathrm{C}$ efflux and there was an increase of $366 \%$ in MB-C after 56-d, indicating high CUE of soil C. This indicates that in short-term (56-d) the preservation of MAOM from decomposition and/or microbial turnover with incorporation of microbial residues-derived $\mathrm{C}$ to MAOM accounted of $10.8 \%$ than unplanted soil under $\mathrm{N}$ limitation condition.

For the planted soil, our second hypothesis was refuted since it was verified a higher positive RPE after 42-d of maize planting to $\mathrm{N}$ addition condition. Maize rhizosphere effect until 56-d of maize growth promoted an increase of $495 \%$ and $50 \%$ in MB-C under no $\mathrm{N}$ addition and $\mathrm{N}$ addition, respectively. The short-term effect (56-d) of maize root in no $\mathrm{N}$ addition soil, besides to preserve native SOM decomposition, allowed higher microbial CUE and consequent incorporation of microbial residues-derived C into the MAOM (14.27\%). However, for the planted soil no shifts in SOM fractions were verified due to $\mathrm{N}$ availability (with and without $\mathrm{N}$ addition), which is opposite to our third hypothesis.

The preservation of the associated-mineral organic matter by $\mathrm{N}$ addition under unplanted soils, and the higher incorporation of $\mathrm{C}$ (rhizodeposits and microbial residues) by maize planting in no $\mathrm{N}$ addition, signs the important issues achieved by our study to design sustainable strategies for ecosystem management. In addition, it reinforces the importance of measuring and modeling the different SOM fractions. New perspectives should be studied further to extend our understanding of the priming effect in tropical conditions, such as the effect of the $\mathrm{N}$ source (ammonia or nitrate) and split fertilization application, besides the importance of the clay and soil organic matter concentrations and phosphorus availability.

\section{Acknowledgements}

This research was financed by the NUTREE group of University Federal of Viçosa. Also, this study was financed in part by the Coordenação de Aperfeiçoamento de Pessoal de Nível Superior-Brasil (CAPES)-Finance Code 001. The authors are grateful to Dr. Rafael Vasconcelos Valadares for his valuable comments that helped to improve the quality of this work.

\section{References}

Arneth, A., Sitch, S., Pongratz, J., Stocker, B. D., Ciais, P., Poulter, B., ... Zaehle, S. (2017). Historical carbon dioxide emissions caused by land-use changes are possibly larger than assumed. Nature Geoscience, 10, 79-84. https://doi.org/10.1038/ngeo2882

Averill, C., \& Waring, B. (2017). Nitrogen limitation of decomposition and decay: How can it occur? Global Change Biology, 12, 3218-3221. https://doi.org/10.1111/gcb.13980

Bingham, A. H., \& Cotrufo, M. F. (2016). Organic nitrogen storage in mineral soil: Implications for policy and management. Science Total Environment, 551-552, 116-126. https://doi.org/10.1016/j.scitotenv.2016.02.020

Blagodatskaya, E., \& Kuzyakov, Y. (2008). Mechanisms of real and apparent priming effects and their dependence on soil microbial biomass and community structure: Critical review. Biology and Fertility of Soils, 45, 115-131. https://doi.org/10.1007/s00374-008-0334-y

Cambardella, C. A., \& Elliott, E. T. (1992). Participate soil organic-matter changes across a grassland cultivation sequence. Soil Science Society of America Journal, 56, 777-783. https://doi.org/10.2136/sssaj1992. $03615995005600030017 \mathrm{x}$

Chen, D., Li, J., Lan, Z., Hu, S., \& Bai, Y. (2016). Soil acidification exerts a greater control on soil respiration than soil nitrogen availability in grasslands subjected to long-term nitrogen enrichment. Functional Ecology, 30, 658-669. https://doi.org/10.1111/1365-2435.12525

Chen, R., Senbayram, M., Blagodatsky, S., Myachina, O., Dittert, K., Lin, X., ... Kuzyakov, Y. (2014). Soil C and $\mathrm{N}$ availability determine the priming effect: Microbial $\mathrm{N}$ mining and stoichiometric decomposition Theories. Global Change Biology, 20, 2356-2367. https://doi.org/10.1111/gcb.12475

Cheng, W. (1999). Rhizosphere feedbacks in elevated $\mathrm{CO}_{2}$. Tree Physiology, 19, 313-320. https://doi.org/ 10.1093/treephys/19.4-5.313

Cheng, W., \& Kuyakov, Y. (2005). Root Effects on soil organic matter decomposition. In R. Zobel, \& S. Wright 
(Eds.), Roots and soil management: Interactions between roots and the soil (pp.119-143). American Society of Agronomy, Madison.

Chowdhury, S., Farrell, M., \& Bolan, N. (2014). Priming of soil organic carbon by malic acid addition is differentially affected by nutrient availability. Soil Biology and Biochemistry, 77, 158-169. https://doi.org /10.1016/j.soilbio.2014.06.027

Cotrufo, M. F., Soong, J. L., Horton, A. J., Campbell, E. E., Haddix, M. L., Wall, D. H., \& Parton, W. J. (2015). Formation of soil organic matter via biochemical and physical pathways of litter mass loss. Nature Geoscience, 8, 776-779.

Cotrufo, M. F., Wallenstein, M. D., Boot, C. M., Denef, K., \& Paul, E. (2013). The Microbial Efficiency-Matrix Stabilization (MEMS) framework integrates plant litter decomposition with soil organic matter stabilization: Do labile plant inputs form stable soil organic matter? Global Change Biology, 19, 988-995. https://doi.org/ 10.1111/gcb.12113

Craine, J. M., Morrow, C. \& Fierer, N. (2007). Microbial nitrogen limitation increases decomposition. Ecology, 88, 2105-2113. https://doi.org/10.1890/06-1847.1

Cyle, K. T., Hill, N., Young, K., Jenkins, T., Hancock, D., Schroeder, P. A., \& Thompson, A. (2016). Substrate quality influences organic matter accumulation in the soil silt and clay fraction. Soil Biology and Biochemistry, 103, 138-148.

Di Lonardo, D. P., De Boer, W., Gunnewiek, P. J. A. K., Hannula, S. E., \& Van der Wal, A. (2017). Priming of soil organic matter: Chemical structure of added compounds is more important than the energy content. Soil Biology and Biochemistry, 108, 41-54. https://doi.org/10.1016/j.soilbio.2017.01.017

Dijkstra, F. A., Carrillo, Y., Pendall, E., \& Morgan, J. A. (2013). Rhizosphere priming: A nutrient perspective. Frontiers in Microbiology, 4, 1-8.

Dilly, O., \& Munch, J. C. (1998). Ratios between estimates of microbial biomass content and microbial activity in soils. Biology and Fertility of Soils, 27, 374-379.

Drake, J. E., Darby, B. A., Giasson, M. A., Kramer, M. A., Philips, R. P., \& Finzi, A. C. (2013). Stoichiometry constrains microbial response to root exudation-insights from a model and a field experiment in a temperate forest. Biogeosciences, 10, 821-838. https://doi.org/10.5194/bg-10-821-2013

Fang, C., Li, F., Pei, J., Ren, J., Gong, Y., Yuan, Z., Ye, J. S. (2018). Impacts of warming and nitrogen addition on soil autotrophic and heterotrophic respiration in a semi-arid environment. Agricultural and Forest Meteorology, 248, 449-457. https://doi.org/10.1016/j.agrformet.2017.10.032

Ferreira, D. F. (2011). Sisvar: A computer statistical analysis system. Ciência e Agrotecnologia, 35, 1039-1042.

Fontaine, S., Henault, C., Aamor, A., Bdioui, N., Bloor, J. M. G., Maire, V., Maron, P. A. (2011). Fungi mediate long term sequestration of carbon and nitrogen in soil through their priming effect. Soil Biology and Biochemistry, 43, 86-96. https://doi.org/10.1016/j.soilbio.2010.09.017

Hodge, A., Grayston, S. J., \& Ord, B. G. (1996). A novel method for characterization and quantification of plant root exudates. Plant and Soil, 184, 97-104. https://doi.org/10.1007/BF00029278

Huo, C., Luo, Y. \& Cheng, W. (2017). Rhizosphere priming effect: A meta-analysis. Soil Biology and Biochemistry, 111, 78-84. https://doi.org/10.1016/j.soilbio.2017.04.003

IPCC. (2014). Climate change 2014 mitigation of climate change. Working group III contribution to the fifth assessment report of the intergovernmental panel on climate change (pp. 1-141). Cambridge University Press, Cambridge. https://doi.org/10.1017/CBO9781107415416.005

Islam, K. R., \& Weil, R. R. (1998). Microwave irradiation of soil for routine measurement of microbial biomass carbon. Biology and Fertility of Soils, 27, 408-416. https://doi.org/10.1007/s003740050451

Jenkinson, D. S., \& Powlson, D. S. (1976). The effect of biocidal treatments on soil metabolism in soil: A method for measuring soil biomass. Soil Biology and Biochemistry, 8, 209-213. https://doi.org/10.1016/ 0038-0717(76)90005-5

Jobbágy, E. G., \& Jackson, R. B. (2000). The vertical distribution of soil organic carbon and its relation to climate and vegetation. Ecological Applications, 10, 423-436. https://doi.org/10.1890/1051-0761(2000) 010[0423:TVDOSO]2.0.CO;2 
Keeling, C. D. (1958). The concentration and isotopic abundances of atmospheric carbon dioxide in rural areas. Geochimica et Cosmochimica Acta, 13, 322-334. https://doi.org/10.1016/0016-7037(58)90033-4

Kleber, M., Sollins, P., \& Sutton, R. (2007). A conceptual model of organo-mineral interactions in soils: Self-assembly of organic molecular fragments into zonal structures on mineral surfaces. Biogeochemistry, 85, 9-24. https://doi.org/10.1007/s10533-007-9103-5

Kraffczyk, I., Trolldenier, G., \& Beringer, H. (1984). Soluble root exudates of maize: Influence of potassium supply and rhizosphere microorganisms. Soil Biology and Biochemistry, 16, 315-322. https://doi.org/ 10.1016/0038-0717(84)90025-7

Kumar, A., Kuzyakov, Y., \& Pausch, J. (2016). Maize rhizosphere priming: Field estimates using ${ }^{13} \mathrm{C}$ natural abundance. Plant and Soil, 409, 87-97. https://doi.org/10.1007/s11104-016-2958-2

Kuzyakov, Y. (2002). Review: Factors affecting rhizosphere priming effects. Journal of Plant Nutrition and Soil Science, 165, 382-396. https://doi.org/10.1002/1522-2624(200208)165:4<382::AID-JPLN382>3.0. CO;2-\#

Kuzyakov, Y., \& Blagodatskaya, E. (2015). Microbial hotspots and hot moments in soil: Concept and review. Soil Biology and Biochemistry, 83, 184-199. https://doi.org/10.1016/j.soilbio.2015.01.025

Kuzyakov, Y., \& Xu, X. (2013). Competition between roots and microorganisms for nitrogen: Mechanisms and ecological relevance. New Phytologist, 198, 656-669. https://doi.org/10.1111/nph.12235

Lehmann, J., \& Kleber, M. (2015). The contentious nature of soil organic matter. Nature, 528, 1-9. https://doi.org/10.1038/nature16069

Liu, X. A., van Groenigen, K. J., Dijkstra, P., \& Hungate, B. A. (2017). Increased plant uptake of native soil nitrogen following fertilizer addition - Not a priming effect? Applied Soil Ecology, 114, 105-110. https://doi.org/10.1016/j.apsoil.2017.03.011

Manzoni, S. (2017). Flexible carbon-use efficiency across litter types and during decomposition partly compensates nutrient imbalances - Results from analytical stoichiometric models. Frontiers in Microbiology, 8, 661. https://doi.org/10.3389/fmicb.2017.00661

Manzoni, S., Taylor, P., Richter, A., Porporato, A., \& Ågren, G. I. (2012). Environmental and stoichiometric controls on microbial carbon-use efficiency in soils. New Phytologist, 196, 79-91. https://doi.org/10.1111/ j.1469-8137.2012.04225.x

Mazzilli, S. R., Kemanian, A. R., Ernst, O. R., Jackson, R. B., \& Piñeiro, G. (2014). Priming of soil organic carbon decomposition induced by corn compared to soybean crops. Soil Biology and Biochemistry, 75, 273-281. https://doi.org/10.1016/j.soilbio.2014.04.005

Meier, I. C., Finzi, A. C., \& Phillips, R. P. (2017). Root exudates increase N availability by stimulating microbial turnover of fast-cycling N pools. Soil Biology and Biochemistry, 106, 119-128. https://doi.org/10.1016/ j.soilbio.2016.12.004

Murphy, C. J., Baggs, E. M., Morley, N., Wall, D. P., \& Paterson, E. (2017). Nitrogen availability alters rhizosphere processes mediating soil organic matter mineralization. Plant and Soil, 417, 499-510. https://doi.org/10.1007/s11104-017-3275-0

Novais R. F., Neves J. C. L., \& Barros N. F. (1991). Ensaio em ambiente controlado. In A. J. Oliveira (Ed.), Métodos de pesquisa em fertilidade do solo (pp. 189-253). Embrapa-SEA, Brasília, Brasil.

Oliveira, D. M. S., Silva, I. R., Mendes, G. O., Vasconcelos, A. A., Mayrink, G. C. V., \& Verburg, E. E. J. (2017). Carbon fluxes from different pools in a mined area under reclamation in Minas Gerais state, Brazil. Land Degradation and Development, 28, 507-514. https://doi.org/10.1002/ldr.2601

Ramnarine, R., Wagner-Riddle, C., Dunfield, K. E., \& Voroney, R. P. (2012). Contributions of carbonates to soil $\mathrm{CO}_{2}$ emissions. Canadian Journal of Soil Science, 92, 599-607. https://doi.org/10.4141/cjss2011-025

Riggs, C. E., \& Hobbie, S. E. (2016). Mechanisms driving the soil organic matter decomposition response to nitrogen enrichment in grassland soils. Soil Biology and Biochemistry, 99, 54-65. https://doi.org/10.1016/ j.soilbio.2016.04.023

Rinkes, Z. L., Bertrand, I., Amin, B. A. Z., Grandy, A. S., Wickings, K., \& Weintraub, M. N. (2016). Nitrogen alters microbial enzyme dynamics but not lignin chemistry during maize decomposition. Biogeochemistry, 128, 171-186. https://doi.org/10.1007/s10533-016-0201-0 
Rousk, J., Bååth, E., Brookes, P. C., Lauber, C. L., Lozupone, C., Caporaso, J. G., ... Fierer, N. (2010). Soil bacterial and fungal communities across a pH gradient in an arable soil. ISME Journal, 4, 1340-1351. https://doi.org/10.1038/ismej.2010.58

Ruiz, H. A. (2005). Incremento da exatidão da análise granulométrica do solo por meio da coleta da suspensão (silte+argila). Revista Brasileira de Ciência do Solo, 29, 297-300. https://doi.org/10.1590/S0100-0683200 5000200015

Schimel, J. P., \& Weintraub, M. N. (2003). The implications of exoenzyme activity on microbial carbon and nitrogen limitation in soil: A theoretical model. Soil Biology and Biochemistry, 35, 549-563. https://doi.org/ 10.1016/S0038-0717(03)00015-4

Shahzad, T., Chenu, C., Genet, P., Barot, S., Perveen, N., Mougi, C., \& Fontaine, S. (2015). Contribution of exudates, arbuscular mycorrhizal fungi and litter depositions to the rhizosphere priming effect induced by grassland species. Soil Biology and Biochemistry, 80, 146-155. https://doi.org/10.1016/j.soilbio.2014.09.023

Sinsabaugh, R. L., Lauber, C. L., Weintraub, M. N., Ahmed, B., Allison, S. D., Crenshaw, C., Zeglin, L. H. (2008). Stoichiometry of soil enzyme activity at global scale. Ecology Letters, 11, 1252-1264. https://doi.org/10.1111/j.1461-0248.2008.01245.x

Six, J., Frey, S. D., Thiet, R. K., \& Batten, K. M. (2006). Bacterial and fungal contributions to carbon sequestration in agroecosystems. Soil Science Society of America Journal, 70, 555-569. https://doi.org/ $10.2136 /$ sssaj2004.0347

Smith, K. A., \& Conen, F. (2004). Measurement of trace gases, I: Gas analysis, Chamber Methods, and Related Procedures. In K. A. Smith, \& M. S. Cresser (Eds.), Soil and Environmental Analysis: Modern Instrumental Techniques (3rd ed., p. 576). New York.

Soil Survey Staff. (2014). Keys to soil taxonomy. Washington DC: USDA-Natural Resources Conservation Service.

Thurgood, A., Singh, B., Jones, E., \& Barbour, M. M. (2014). Temperature sensitivity of soil and root respiration in contrasting soils. Plant and Soil, 382, 253-267. https://doi.org/10.1007/s11104-014-2159-9

Ward, D., Kirkman, K., Hagenah, N., \& Tsvuura, Z. (2017). Soil respiration declines with increasing nitrogen fertilization and is not related to productivity in long-term grassland experiments. Soil Biology and Biochemistry, 115, 415-422. https://doi.org/10.1016/j.soilbio.2017.08.035

White, D., Drummond, J., \& Fuqua, C. (2012). The Physiology and Biochemistry of Prokryotes (4th ed.). Oxford University Press, Hong Kong.

Zang, H., Blagodatskaya, E., Wang, J., Xu, X., \& Kuzyakov, Y. (2017). Nitrogen fertilization increases rhizodeposit incorporation into microbial biomass and reduces soil organic matter losses. Soil Biology and Biochemistry, 53, 419-429.

Zhu, B., Panke-Buisse, K., \& Kao-Kniffin, J. (2015). Nitrogen fertilization has minimal influence on rhizosphere effects of smooth crabgrass (Digitaria ischaemum) and bermudagrass (Cynodon dactylon). Journal of Plant Ecology, 8, 390-400. https://doi.org/10.1093/jpe/rtu034

\section{Copyrights}

Copyright for this article is retained by the author(s), with first publication rights granted to the journal.

This is an open-access article distributed under the terms and conditions of the Creative Commons Attribution license (http://creativecommons.org/licenses/by/4.0/). 